\title{
Rancang Bangun Sistem Anti Overloading Pada Kendaraan Barang Berbasis Mikrokontroler Menggunakan Sensor Jarak
}

\author{
Dhea Ahmad Rivaldy ${ }^{1}$, Agus Sasmito ${ }^{2}$, Tri Handoyo ${ }^{3}$ \\ Program Studi Teknik Keselamatan Otomotif, Politeknik Keselamatan Transportasi Jalan \\ E-mail: dheaahmadrivaldy@gmail.com
}

Received 16 September 2020; Reviewed 4 November 2020; Accepted 10 November 2020 Journal Homepage: http://ktj.pktj.ac.id/index.php/ktj

DOI: $10.46447 / k t j . v 7 i 2.169$

\begin{abstract}
Abstrak
Kendaraan barang yang selama ini diandalkan sebagai alat distribusi barang nampaknya memiliki berbagai permasalahan. Masalah yang muncul adalah akibat dari kelalaian pengguna dengan memberikan beban muatan yang berlebih pada kendaraan tersebut. Berbagai permasalahan yang dapat terjadi karena muatan berlebih pada angkutan barang apabila tidak ditanggapi dengan serius dapat menyebabkan kerugian yang semakin besar. Memanfaatkan teknologi saat ini, dikembangkannya sebuah sistem anti overloading pada kendaraan barang yang dapat mengatasi permasalahan kelebihan muatan. Di dalam perancangan alat ini perlu dilakukan eksperimen awal untuk mencari batas jarak beban aman sebagai dasar membuat program. Metode penelitian yang digunakan pada penelitian ini adalah Research and Development (R\&D) yang merupakan suatu proses untuk mengembangkan produk baru atau menyempurnakan produk yang telah ada. Desain pemasangan dari sistem anti overloading pada rangka chasis bawah untuk mendeteksi batas jarak beban aman dan beban muatan antara rangka chasis bawah dengan dumper kendaraan. Kinerja sistem menggunakan sensor jarak pada alat peraga dengan beban yang diberikan dapat bekerja dengan baik serta alat dapat memberikan kinerja output sesuai dengan pemrograman yang telah dirancang seperti menampilkan hasil pembacaan jarak dan beban muatan pada handphone Android. Tingkat akurasi dari fungsi sensor terhadap pembacaan jarak memiliki persentase ratarata success $100 \%$ dan error $0 \%$.
\end{abstract}

Kata kunci: Kelebihan Muatan, Mikrokontroler, Sensor Ultrasonik, Android

\section{PENDAHULUAN}

Transportasi sering dianggap sebagai prasyarat pembangunan ekonomi, karena pertumbuhan ekonomi memerlukan transportasi dan pembangunan infrastruktur (Mahmudah et al., 2011). Namun demikian, pertumbuhan ekonomi juga akan meningkatkan jumlah ton-km transportasi barang. Sebagaimana dicatat oleh Direktorat Jenderal Perhubungan Darat Republik Indonesia (2006) transportasi barang yang menggunakan jalan diperkirakan mencapai $91,25 \%$. Angka ini jauh lebih tinggi dibandingkan dengan yang menggunakan moda transportasi kereta api $(0,63 \%)$, moda sungai $(1,01 \%)$ dan moda laut $(7 \%)$ (Mahmudah et al., 2011)

Kendaraan angkut barang yang selama ini diandalkan sebagai alat distribusi barang dari produsen ke konsumen nampaknya memiliki berbagai permasalahan 
apabila diamati dalam kehidupan sehari-hari. Masalah yang muncul tak lain adalah akibat dari kelalaian pengguna kendaraan angkut barang itu sendiri dengan memberikan beban yang berlebih pada kendaraan tersebut. Melihat kondisi lalu lintas di Indonesia saat ini, sering sekali ditemui kendaraan angkut barang dengan sasis yang tidak simetris, kendaraan angkut barang yang berjalan tidak seimbang, bahkan kendaraan angkut barang mogok di tengah jalan karena patah as-rodanya akibat dari beban yang diangkut terlampau jauh melewati batas maksimal beban muatan kendaraan. Selain itu, kendaraan yang mengangkut beban muatan yang melebihi batas maksimal beban muatan kendaraan dapat menimbulkan kerusakan pada badan jalan. Hal ini tentunya menimbulkan dampak yang merugikan pengguna jalan yang lain. Kendaraan angkut barang yang mogok di jalan menyebabkan kemacetan yang berlarut-larut karena ukuran kendaraan angkut barang yang sangat besar sehingga memakan banyak badan jalan (Santoso et al., 2012).

Upaya pencegahan terhadap kelebihan muatan telah dilakukan oleh berbagai pihak. Sebagai upaya untuk mengatasi kelebihan muatan pemerintah telah menetapkan peraturan pembatasan dari maksimal beban angkut kendaraan yang tercantum dalam UU No. 22 Tahun 2009 yang dilakukan dengan menggunakan alat penimbangan. Penanggulangan untuk mengatasi kelebihan muatan dengan menggunakan alat penimbangan atau jembatan timbang tersebut belum berjalan dengan efektif karena masih banyak pengemudi yang tidak mematuhi aturan muatan kendaraan (Firdaus et al., 2019).

Berdasarkan permasalahan tersebut, sangat perlu dikembangkan sebuah sistem anti overloading pada kendaraan barang yang dapat mengatasi permasalahan kelebihan muatan dengan memanfaatkan berkembangnya teknologi saat ini. Di dalam perancangan alat ini perlu dilakukan eksperimen awal untuk mencari batas jarak beban aman antara rangka chasis bawah dengan dumper menggunakan sensor jarak berdasarkan beban muatan yang diberikan sesuai dengan Jumlah Berat Yang Diperbolehkan (JBB). Tujuan dari alat ini adalah sebagai sistem pembatas muatan pada kendaraan barang dalam upaya meningkatkan keselamatan dijalan dan dapat menghentikan kerja mesin saat kendaraan dalam muatan berlebih atau overloading sehingga kendaraan dengan muatan berlebih tidak dapat dioperasikan.

\section{METODE}

Metode penelitian yang digunakan dalam penelitian ini adalah Research and Development (R\&D). Research and Development (R\&D) merupakan suatu proses untuk mengembangkan suatu produk baru atau menyempurnakan produk yang telah ada. Penyempurnaan alat yang peneliti lakukan akan diuji coba. Uji coba produk menentukan keberhasilan alat yang telah dirancang.

Software yang dibutuhkan dalam perancangan alat adalah aplikasi Fritzing, Arduino IDE dan Blynk. Sedangkan hardware yang dibutuhkan dalam perakitan komponen, meliputi Wemos D1 R2, sensor jarak ultrasonik (HC-SR04), LED, buzzer, relay, motor servo dan project board. 


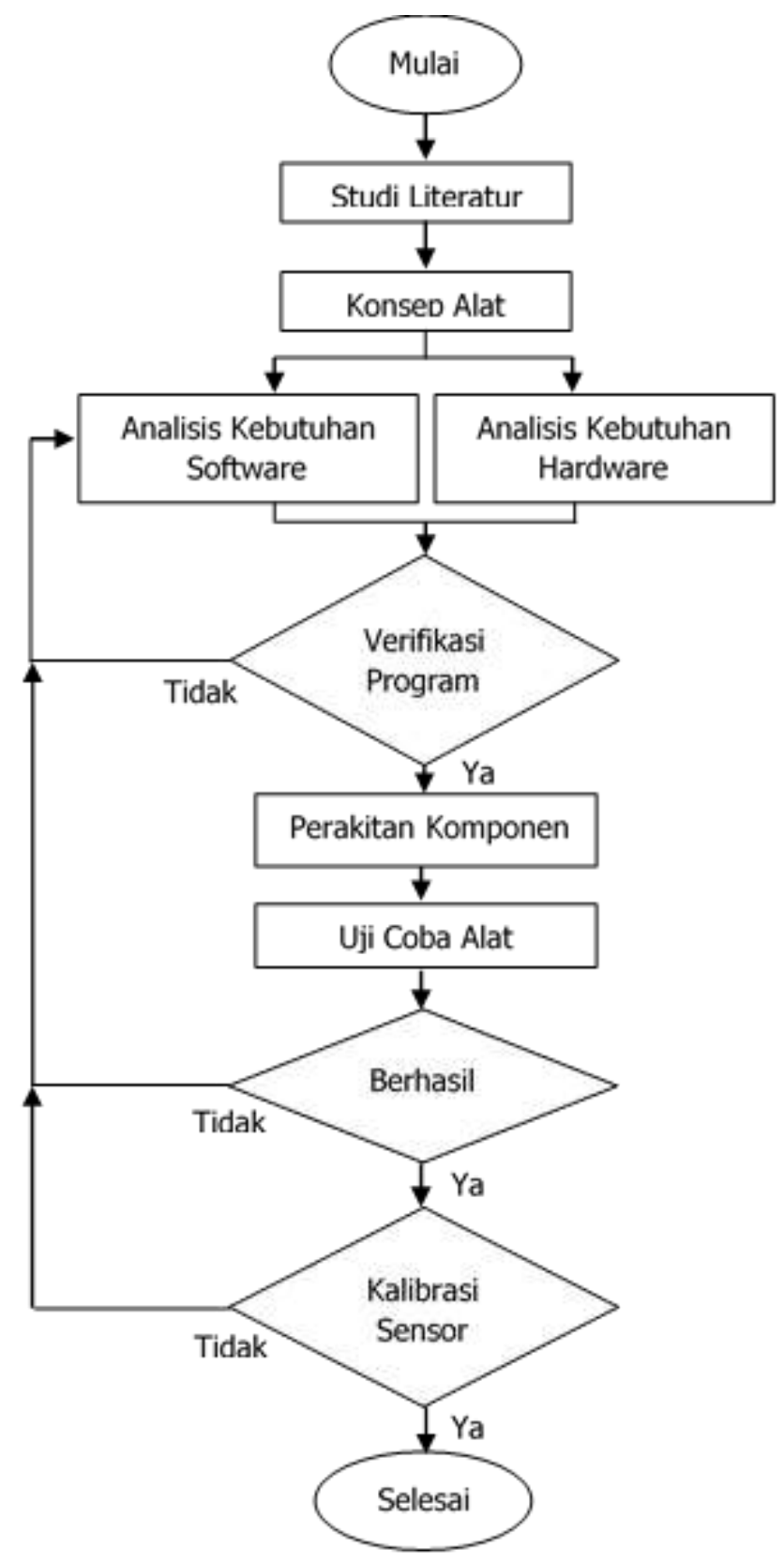

Gambar 1. Diagram Alir Penelitian

Verifikasi program dilakukan untuk pemeriksaan kesesuaian jalannya model logika yang sudah diprogram komputer dengan yang diinginkan. Berikut adalah proses verifikasi program yang dilakukan oleh peneliti : 


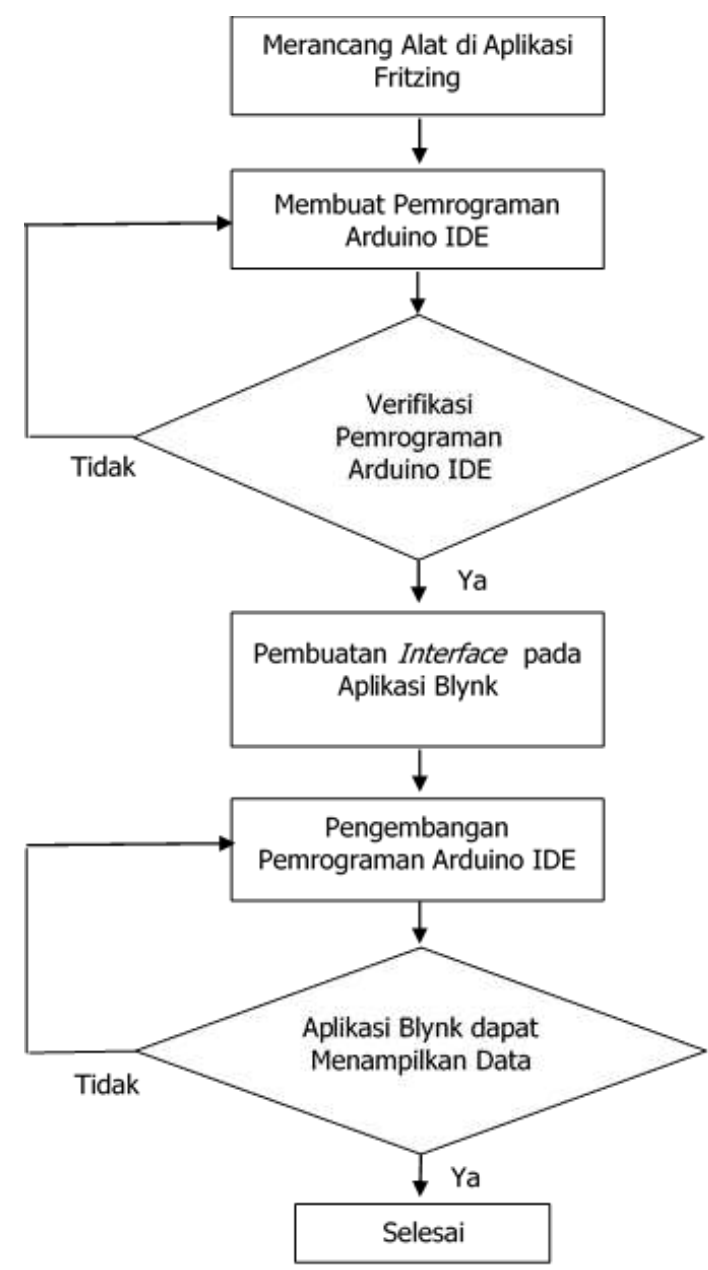

Gambar 2. Proses Verifikasi Program

Perakitan alat dilakukan secara keseluruhan yang berkaitan dengan sistem perangkat keras sesuai dengan rangkaian dan simulasi yang telah diprogram, terdiri dari komponen pemasukan data, komponen pengolahan data dan komponen keluaran data. Diagram blok sistem menunjukkan konsep dasar dari prototype dapat dilihat pada Gambar 3.

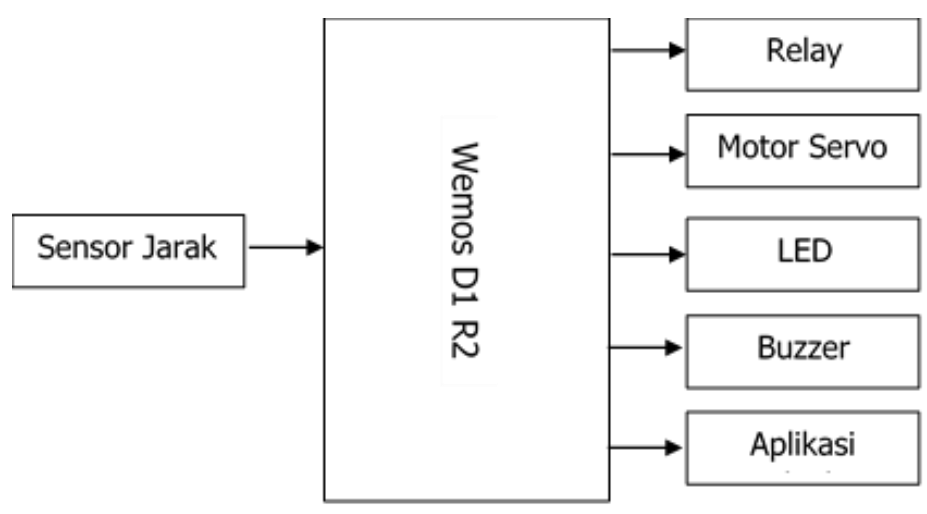

Gambar 3. Diagram Sistem Prototype 


\section{HASIL DAN PEMBAHASAN}

\section{Data Perhitungan Batas Jarak Beban}

Perhitungan batas jarak beban aman berdasarkan beban muatan yang diberikan pada kendaraan sesuai dengan Jumlah Berat Yang Diperbolehkan (JBB) sebagai dasar dalam membuat program dan konsep alat. Perhitungan batas jarak beban aman dari variasi muatan yang diberikan yaitu dimulai pada kondisi berat kosong kendaraan, hingga mencapai muatan berlebih atau overloading dan hasilnya dapat dilihat pada tabel berikut :

Tabel 1. Rekapitulasi Data Perhitungan Jarak Beban

\begin{tabular}{ccc} 
Penambahan Beban & Jarak Beban & Keterangan \\
\hline $559 \mathrm{~kg}$ & $6 \mathrm{~cm}$ & Berat Kosong \\
\hline $984 \mathrm{~kg}$ & $5 \mathrm{~cm}$ & $75 \%$ Berat \\
\hline $1.509 \mathrm{~kg}$ & $3 \mathrm{~cm}$ & $100 \%$ Berat \\
\hline $1.719 \mathrm{~kg}$ & $1 \mathrm{~cm}$ & $110 \%$ Berat \\
\hline
\end{tabular}

Dari hasil perhitungan batas jarak beban aman diatas, menghasilkan jarak beban dari variasi muatan yang diberikan. Pada kondisi kendaraan berat kosong dengan beban muatan $559 \mathrm{~kg}$ menghasilkan jarak beban sebesar $6 \mathrm{~cm}$. Pada kondisi kendaraan $75 \%$ beban penuh dengan beban muatan $984 \mathrm{~kg}$ menghasilkan jarak beban sebesar $5 \mathrm{~cm}$. Pada kondisi kendaraan mencapai $100 \%$ beban penuh dengan beban muatan $1509 \mathrm{~kg}$ menghasilkan jarak beban sebesar $3 \mathrm{~cm}$. Pada kondisi kendaraan mencapai $110 \%$ beban penuh atau overloading dengan muatan $1719 \mathrm{~kg}$ menghasilkan jarak beban sebesar $1 \mathrm{~cm}$. Berdasarkan kondisi beban muatan kendaraan sesuai dengan Jumlah Berat Yang Diperbolehkan (JBB) diperoleh batas jarak beban aman sebesar $3 \mathrm{~cm}$. Batas jarak beban aman tersebut sebagai dasar di dalam membuat program sistem anti overloading dengan unjuk kerja pada alat ketika sensor jarak ultrasonik (HCSR04) mendeteksi jarak beban dibawah $3 \mathrm{~cm}$ maka output akan bekerja untuk menghentikan kinerja mesin sehingga kendaraan dengan kondisi muatan overloading tidak dapat dioperasikan.

\section{Uji Coba Alat}

Uji coba alat dilakukan dengan menggunakan alat peraga untuk memastikan bahwa kinerja dari sensor jarak dapat mendeteksi serta mengukur jarak beban aman dan beban muatan yang diterima, selanjutnya menilai hasil perakitan komponen dapat bekerja dengan baik sesuai dengan prinsip kerjanya. Tahap uji coba pada alat peraga ini dilakukan dengan tiga tahap. Setiap tahap akan mewakili dari kinerja input maupun output yang diberikan. Berikut adalah penjelasan lebih lanjut mengenai uji coba awal tersebut.

\section{Tahap 1}

Pada tahap pertama adalah dengan memberikan beban kosong pada alat peraga. Diketahui hasil pembacaan jarak beban dan beban muatan pada handphone Android serta lampu LED hijau menyala sebaga indikator aman. 

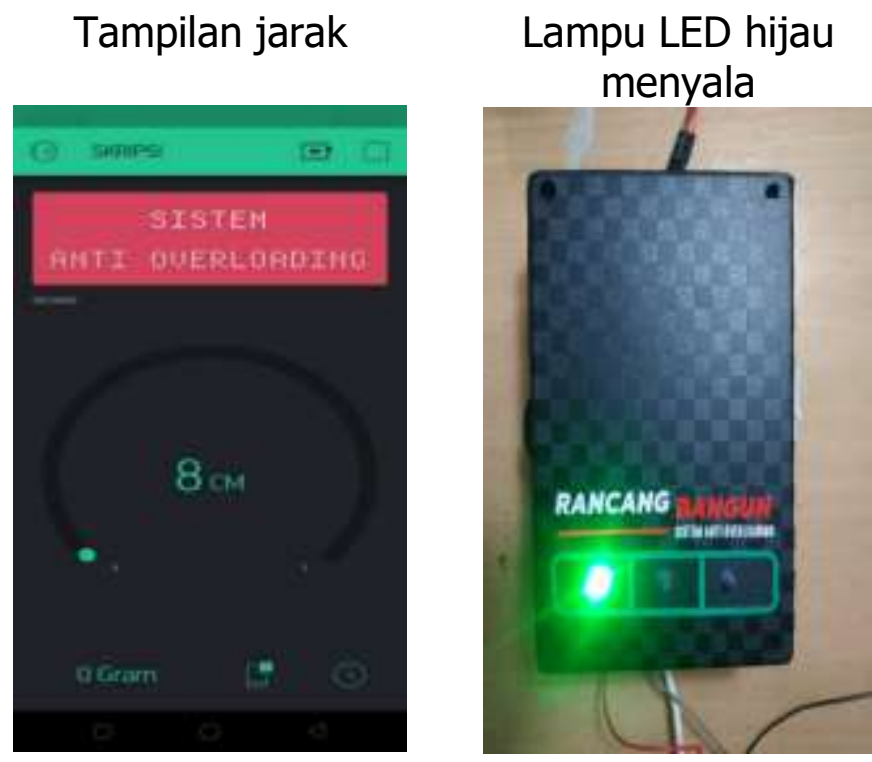

Gambar 4. Uji Coba Tahap 1

\section{Tahap 2}

Pada tahap kedua adalah dengan memberikan beban muatan sebesar 4640 gram pada alat peraga. Diketahui hasil pembacaan jarak beban dan beban muatan pada handphone Android, lampu LED berkedip-kedip sebagai indikator peringatan bahaya muatan berlebih atau overloading dan buzzer berbunyi sebagai indikator alarm peringatan.
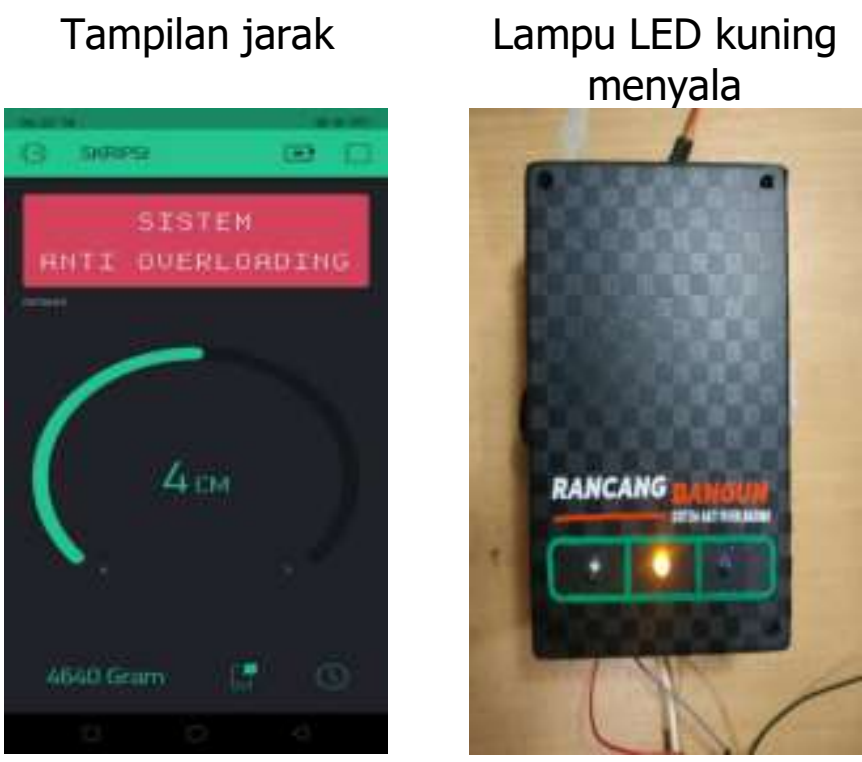

\section{Tahap 3}

Gambar 5. Uji Coba Tahap 2

Pada tahap ketiga adalah dengan memberikan beban muatan berlebih sebesar 5800 gram pada alat peraga, diketahui hasil pembacaan jarak beban dan beban muatan serta notifikasi pada handphone Android, lampu LED merah menyala dan buzzer berbunyi sebagai indikator muatan berlebih, motor servo 
bergerak dan relay yang sebelumnya bersifat normally open akan bersifat normally close.

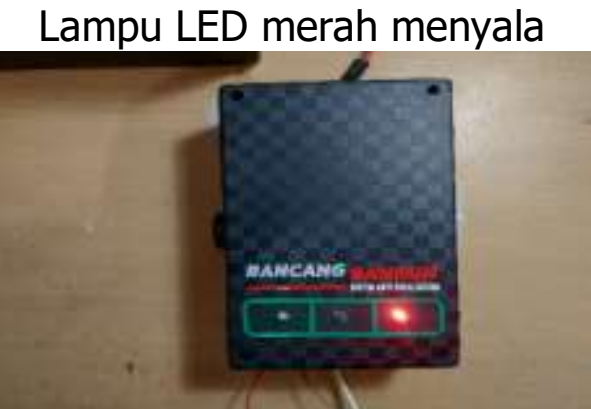

Motor Servo Bergerak

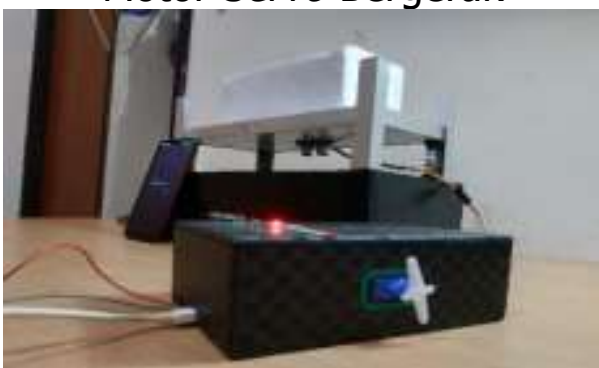

Gambar 6. Uji Coba Tahap 3
Buzzer berbunyi

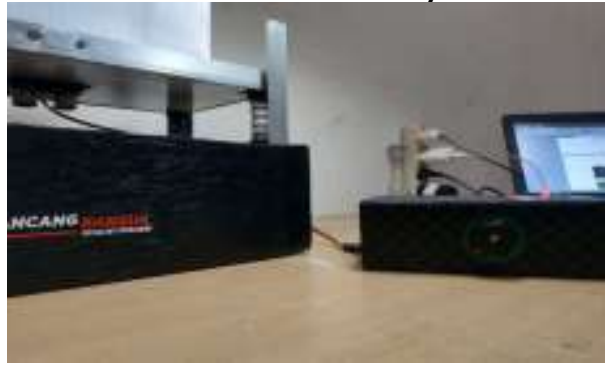

Relay menghentikan putaran

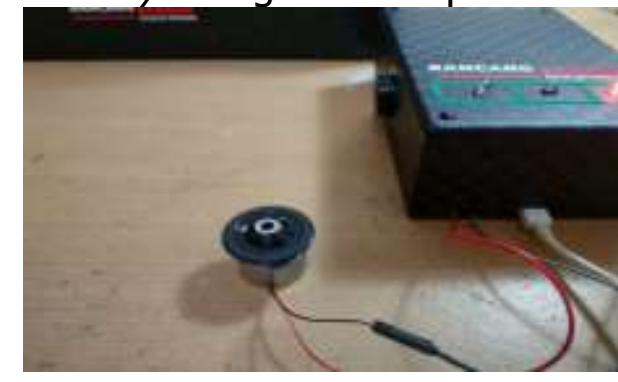

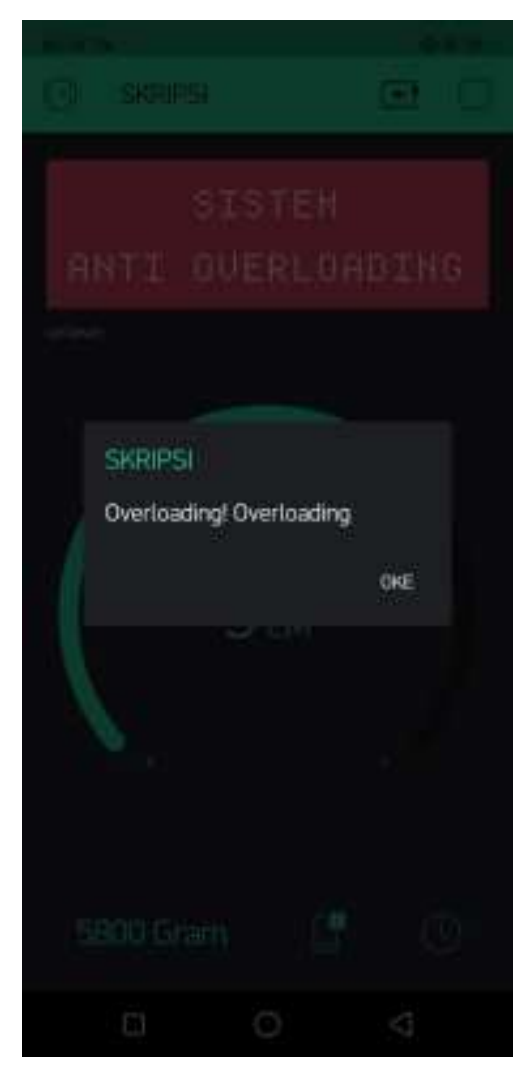

Gambar 7. Notifikasi Pada Handphone Android 


\section{Hasil Uji Coba Alat}

Tabel 2. Hasil Uji Coba

\begin{tabular}{ccccccc}
\hline Beban & Jarak & \multicolumn{4}{c}{ Kondisi } & Keterangan \\
\cline { 3 - 6 } & LED & Buzzer & Motor Servo & Relay & Lotan \\
\hline Beban Kosong & $8 \mathrm{~cm}$ & Hijau & Low & Low & Low & Sesuai \\
\hline $\begin{array}{c}\text { Beban Muatan } \\
4640 \mathrm{gr}\end{array}$ & $4 \mathrm{~cm}$ & Kuning & High & Low & Low & Sesuai \\
\hline $\begin{array}{c}\text { Beban Berlebih } \\
5800 \mathrm{gr}\end{array}$ & $3 \mathrm{~cm}$ & Merah & High & High & High & Sesuai \\
\hline
\end{tabular}

Sumber : Hasil Pengujian, 2020

Hasil uji coba alat yaitu alat dapat mendeteksi serta mengukur batas jarak beban aman dan beban muatan sebagai sistem pembatas muatan pada alat peraga. Alat ini juga dapat memberikan kinerja output sesuai dengan pemrograman yang telah dirancang pada mikrokontroler seperti menampilkan hasil pembacaan jarak dan beban muatan pada handphone Android yang sudah terpasang aplikasi Blynk. Pemrograman yang telah dibuat menggunakan Software Arduino IDE dan diupload pada mikrokontroler Wemos D1 R2.

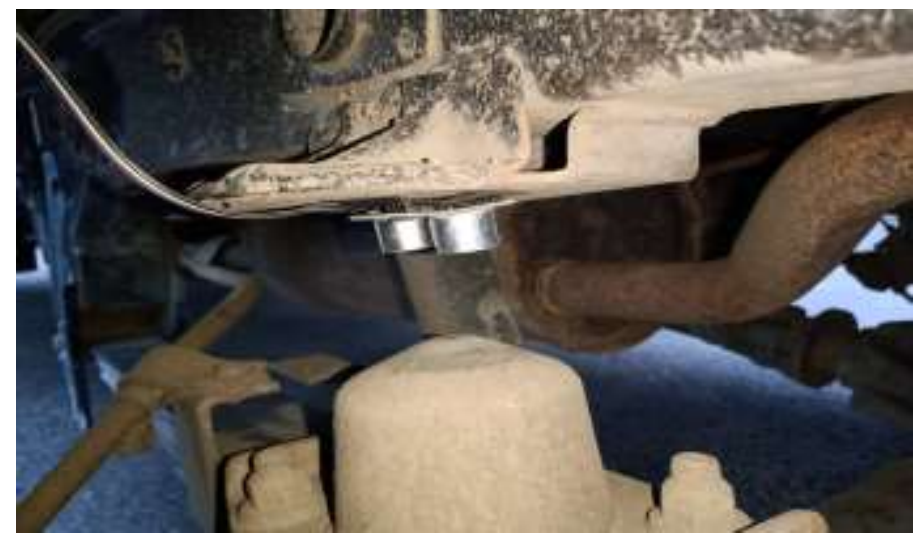

Gambar 8. Pemasangan Sensor Jarak Ultrasonik (HC-SR04)

Gambar 8. merupakan desain pemasangan dari sistem anti overloading menggunakan sensor jarak ultrasonik (HC-SR04) sebagai pendeteksi batas jarak beban aman dan beban muatan antara chasis bawah dengan dumper kendaraan.

Tabel 3. Rekapitulasi Data Hasil Kalibrasi Sensor Jarak Ultrasonik (HC-SR04)

\begin{tabular}{ccccc}
\multirow{2}{*}{ Percobaan } & \multicolumn{2}{c}{ Jarak (cm) } & Success (\%) & Error (\%) \\
\cline { 2 - 4 } & Penggaris & Sensor & & \\
\hline 1 & 2 & 2 & $100 \%$ & $0 \%$ \\
\hline 2 & 3 & 3 & $100 \%$ & $0 \%$ \\
\hline 3 & 4 & 4 & $100 \%$ & $0 \%$ \\
\hline 4 & 5 & 5 & $100 \%$ & $0 \%$ \\
\hline 5 & 6 & 6 & $100 \%$ & $0 \%$ \\
\hline & Rata - rata & & $100 \%$ & $0 \%$ \\
\hline
\end{tabular}

Sumber : Hasil Pengujian, 2020 


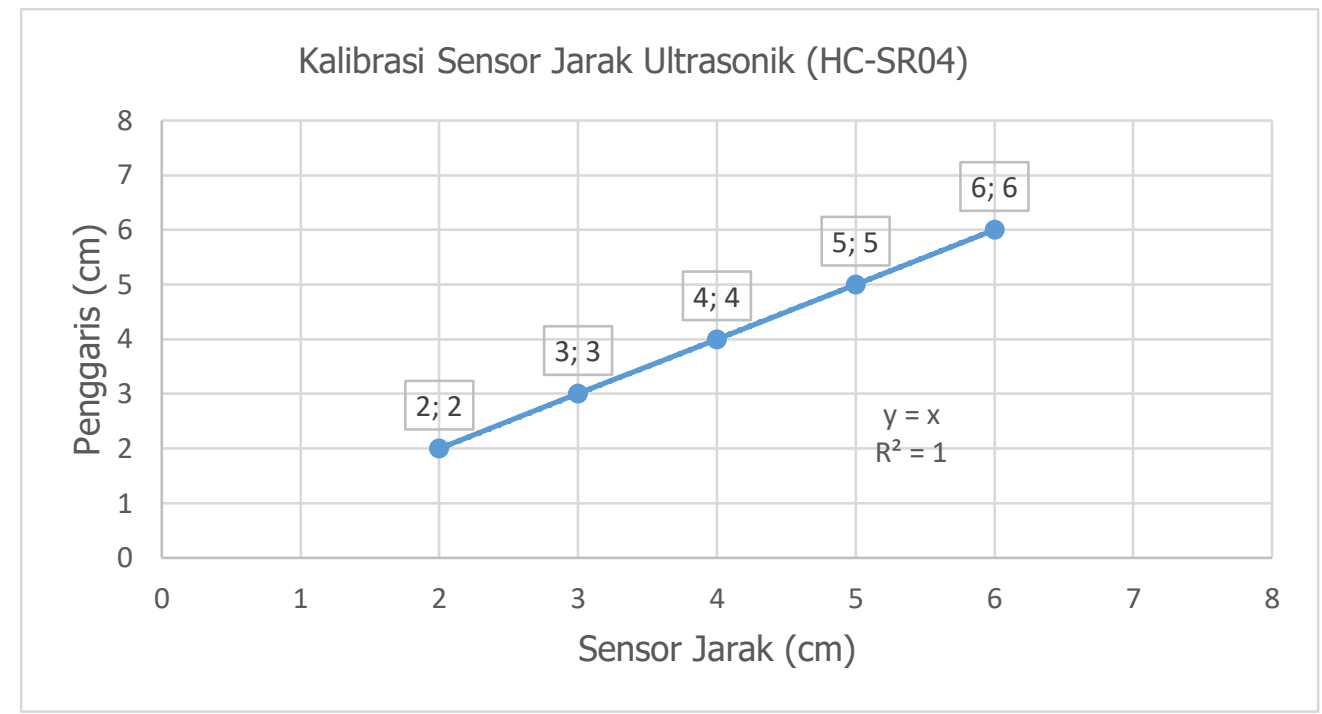

Gambar 9. Grafik Kalibrasi Sensor Jarak Ultrasonik (HC-SR04)

Berdasarkan hasil kalibrasi sensor jarak ultrasonik (HC-SR04) dan grafik hubungan antara sensor terhadap penggaris sebagai tolak ukur memiliki persentase rata-rata success $100 \%$ dan error $0 \%$. Kemudian diperoleh persamaan $y=x$ dengan nilai koefisiensi korelasi linier sebesar $R^{2}=1$. Hal ini menunjukkan bahwa sensor dapat bekerja akurat dan optimal. Selain itu, terjadinya hubungan yang kuat dan searah antara alat yang dibuat peneliti dengan penggaris sebagai tolak ukur.

\section{SIMPULAN}

Berdasarkan hasil data perhitungan, perancangan dan pengujian rancang bangun sistem anti overloading pada kendaraan barang berbasis mikrokontroler menggunakan sensor jarak diketahui bahwa penentuan batas jarak beban aman berdasarkan beban muatan yang diberikan pada mobil barang Daihatsu Gran Max (Pick Up) sesuai dengan Jumlah Berat Yang Diperbolehkan (JBB) sebesar $3 \mathrm{~cm}$. Batas jarak beban aman tersebut sebagai dasar didalam membuat program sistem anti overloading dengan unjuk kerja pada alat ketika sensor jarak ultrasonik (HC-SR04) mendeteksi jarak beban dibawah $3 \mathrm{~cm}$, maka output LED merah akan menyala, buzzer berbunyi sebagai indikator muatan berlebih, motor servo bergerak, relay menghentikan kinerja mesin serta notifikasi pada handphone Android. Hasil uji coba alat yaitu alat dapat mendeteksi serta mengukur batas jarak beban aman dan beban muatan sebagai sistem pembatas muatan pada alat peraga. Alat ini juga dapat memberikan kinerja output sesuai dengan pemrograman yang telah dirancang pada mikrokontroler. Desain pemasangan dari sistem anti overloading menggunakan sensor jarak ultrasonik (HC-SR04) pada chasis bawah untuk mendeteksi batas jarak beban aman dan beban muatan antara rangka chasis bawah dengan dumper kendaraan. Tingkat akurasi dari fungsi sensor terhadap pembacaan jarak yang dibandingkan dengan alat pengukur sebagai tolak ukur memiliki persentase rata-rata success $100 \%$ dan error $0 \%$. 


\section{SARAN}

Diperlukan penelitian dan evaluasi lebih lanjut untuk dapat diaplikasikan pada kendaraan barang.

\section{DAFTAR PUSTAKA}

Andayani Martalia, I. W. (2016). Kalibrasi Sensor Ultrasonik HC-SR04 Sebagai Sensor Pendeteksi Jarak Pada Prototipe Sistem Peringatan Dini Bencana Banjir. Prosiding Seminar Nasional Fisika (E-Journal) SNF2016 (pp. p-ISSN : 2339-0654). Jakarta: Program Studi Fisika Fakultas Matematika dan Ilmu Pengetahuan Alam Universitas Negeri Jakarta.

Apriantoro, R., Firmansyah, A., Utami, T., Tohirin, \& Suharjono, A. (2016). Lolis (Load Limiting System). Seminar Nasional Terapan Riset Inovatif SEMARANG, 15 - 16 Oktober 2016, 301-307.

Baihaqi, S. B., Atmawan, S., Dwifa, M. B., \& Budi, S. S. (2015). Rancang Bangun Deteksi Overload Sebagai Kendali Automatic Engine Cut Off dengan Mikrokontroler Menggunakan Sensor Potensiometer. The 18th FSTPT International Symposium, Unila, Bandar Lampung,August 28, 2015.

Firdaus, R., Lutfi, L., Anshor, M. H., \& Kurnia, R. (2019). Otomatisasi Sensor Load Cell untuk Mengatasi Overload Kendaraan. Jurnal Nasional Teknik Elektro, Vol. 8, No. 2, Juli 2019 , 81-88.

Limantara, A. D., Purnomo, Y. C., \& Mudjanarko, S. W. (2017). Pemodelan Sistem Pelacakan Lot Parkir Kosong Berbasis Sensor Ultrasonic dan Internet Of Things (IOT) Pada Lahan Parkir Diluar Jalan. Seminar Nasional Sains dan Teknologi 2017.

Mahmudah, N., Parikesit, D., Malkhamah, S., \& Priyanto, S. (2011). Pengembangan Metodologi Perencanaan Transportasi Barang Regional. Jurnal Transportasi Vol. 11 No. 3 Desember 2011, 173-182.

Peraturan Menteri Perhubungan Republik Indonesia Nomor PM 60 Tahun 2019 tentang Penyelenggaraan Angkutan Barang dengan Kendaraan Bermotor di Jalan. Jakarta

Peraturan Menteri Perhubungan Nomor KM. 49 tahun 2005 tentang Sistem Transportasi Nasional (SISTRANAS). Jakarta

Peraturan Pemerintah Republik Indonesia Nomor 55 Tahun 2012 tentang Kendaraan. Jakarta

Santoso, R. H. (n.d.) (2012). Mendesain Sensor Berat Untuk Kendaraan Angkutan Barang Mitsubishi L-300. Jalan Siwalankerto 121-131, Surabaya 60236, Indonesia: Jurusan Teknik Mesin Universitas Kristen Petra.

Suryono, B. S. (2013). Sistem Akuisis Data Komputer Pada Sensor Ultrasonic Ranger Untuk Pengukuran Level Muka Air. Berkala Visika, Vol.16, No. 4, 139-144.

Surat Edaran Direktur Jenderal Perhubungan Darat Nomor SE.02/AJ.208/DRJD/2008 tentang Panduan Batasan Maksimum Perhitungan JBI (Jumlah Berat yang diIzinkan) dan JBKI (Jumlah Berat Kombinasi yang diIzinkan) untuk Mobil Barang, Kendaraan Khusus, Kendaraan Penarik berikut Kereta Tempelan/Kereta Gandengan. Jakarta

Vera Firmansyah, S. H. (2020). Pemanfaatan Sensor Ultrasonik sebagai Alat Bantu Pembacaan Skala Volume pada Bell Prover. J.Otto.Ktrl.Inst (J.Auto.Ctrl.Inst), ISSN : 2085-2517. 
Zulkarnaen, T. R. (2011). Implementasi Kebijakan Pengawasan dan Pengendalian Muatan Lebih (Studi Kasus pada Unit Pelaksana Penimbangan Kendaraan Bermotor Dinas Perhubungan Provinsi Sumatera Utara). Vol . 2, No.1, Desember 2011, 209-231. 